\title{
Pertumbuhan rumput jepang (Zoysia japonica) pada berbagai tingkat kemiringan dengan aplikasi Hydroseeding
}

\author{
Anisa Zairina $\left.{ }^{1 *}\right)$, Sri Sulastri ${ }^{2}$, Agus Sukarno $^{3}$, Diena Widyastuti $^{4}$ \\ ${ }_{1,2,3}$ Fakultas Kehutanan. Institut Pertanian Malang, Indonesia \\ ${ }^{4}$ Fakultas Teknologi Pertanian. Institut Pertanian Malang, Indonesia \\ ${ }^{*}$ Koresponden Penulis : anisa.zairina85@gmail.com
}

\begin{abstract}
ABSTRAK
Hydroseeding merupakan salah satu teknik penanaman benih dengan formulasi yang dapat disebarkan dengan penyemprotan. Penelitian tentang Hydroseeding di Indonesia masih masih jarang dilakukan. Penerapan teknik hydroseeding ini dapat dikembangkan untuk pengelolaan longsor. Penelitian ini bertujuan untuk menganalisis tingkat persentase pertumbuhan (viabilitas) dan pertumbuhan Rumput Jepang (Zoysia japonica) yang ditanam pada media tanah bekas longsor pada berbagai tingkat kemiringan. Penelitian ini dilaksanakan di Laboratorium Sentral dan rumah kaca Institut Pertanian Malang pada bulan Maret - Juli 2020. Media tanah yang digunakan diperoleh dari tanah longsor di Ngantang Kabupaten Malang. Sebanyak 5 kg media dimasukkan ke dalam kotak plastik. Kemudian kotak diletakkan pada rak dengan kemiringan $30^{\circ}, 50^{\circ}$, dan $70^{\circ}$. Benih Rumput Jepang yang diperoleh dari pasar dicampur dengan kompos, kondisioner tanah, guar gum, air untuk membentuk formula Hydroseeding. Formula kemudian disemprotkan ke media tanam. Hasil penelitian menunjukkan bahwa aplikasi hydroseeding dengan benih rumput Jepang (Z. japonica) pada media yang diletakkan dengan kemiringan $70^{\circ}$ potensial digunakan sebagai formula untuk proses revegetasi lahan bekas longsor. Perlakuan hydroseeding pada kemiringan $70^{\circ}$ ini menghasilkan viabilitas benih dan laju pertumbuhan yang paling tinggi. Dengan demikian, Rumput Jepang (Z. japonica) potensial digunakan sebagai tanaman pionir dalam reklamasi lahan.
\end{abstract}

Kata kunci: lahan kritis, longsor, reklamasi, revegetasi, tumbuhan pionir

\begin{abstract}
Hydroseeding is a technique for planting seeds with a formulation that can be spread by spraying. Research on Hydroseeding in Indonesia is still rarely done. The application of this hydroseeding technique can be developed for landslide control. This study aims to analyze the percentage of growth (viability) and growth of Japanese grass (Zoysia japonica) planted on landslide soil media at various levels of slope. Experiments were conducted in the Central Laboratory and greenhouse of the Institut Pertanian Malang in April - June 2020. The soil for planting media was collected from post landslides in Ngantang, Malang, East Java, Indonesia. A total of $5 \mathrm{~kg}$ of media was put in a plastic box. Then the box is placed on a shelf with a slope of $30^{\circ}, 50^{\circ}$, and $70^{\circ}$. Japanese Grass seeds werepuchased from the on-line market, then mixed with water, soil stabilizer. Results showed that the application of hydroseeding with Japanese grass seed (Z. japonica) on media placed with a slope of $70^{\circ}$ could potentially be used as a formula for the revegetation process of landslide-affected land. The hydroseeding treatment at this slope resulted in the highest seed viability and growth rate. Thus, Japanese grass (Z. japonica) has the potential to be used as a pioneer plant in land reclamation.
\end{abstract}

Keywords: critical land, landslide, reclamation, revegetation, pioneer plant

doi: $10.33474 /$ e-jbst.v7i2.477

Diterima tanggal 1 Desember 2021- Diterbitkan Tanggal 29 Januari 2022 http://creativecommons.org/licenses/by/4.0 


\section{Pendahuluan}

Lahan kritis merupakan lahan yang sulit ditanami sehingga tidak bisa menjadi lahan budidaya. Dari tahun 2011 hingga 2016, sebanyak 12,31\% lahan kritis di Indonesia telah terdegradasi. Lahan kritis dapat terjadi secara alamiah maupun akibat aktivitas manusia. Akibatnya, sekitar 14 miliar hektar lahan kritis sangat perlu dikonservasi karena berdampak signifikan terhadap keberlanjutan sosial ekonomi masyarakat terutama petani. Lahan kritis adalah lahan kritis yang telah kehilangan fungsi utamanya sebagai pengatur tata air, suplai produksi pertanian, dan elemen pelindung lingkungan. Lahan kritis terjadi karena proses degradasi sifat kimia, fisika dan biologi tanah [1]. Pemulihan lahan kritis melibatkan kegiatan dan kebijakan berbagai institusi yang saling terkait. Meskipun upaya rehabilitasi lahan telah dilakukan melalui penghijauan dan program lainnya, namun belum seluruhnya mampu mengatasi luasnya lahan kritis [1]. Upaya revegetasi di lapangan seringkali tidak layak karena aksesibilitas, kerusakan lahan, partisipasi masyarakat, cuaca, pendanaan dll. Lahan kritis umumnya terjadi di daerah dengan aksesibilitas rendah, curam dan rapuh.

Indonesia merupakan salah satu negara sering dilanda berbagai bahaya dan bencana alam. Salah satu kejadian bencana tersebut adalah terjadinya tanah longsor. Sebagian besar daerah perbukitan dan pegunungan di Jawa memiliki karakteristik tanah yang rentan [2]. Peningkatan luasan lahan budidaya pertanian dan pemukiman menyebabkan terdegradasinya lahan. Beberapa lahan kosong akibat longsor, dengan tingkat lereng curam membutuhkan revegetasi [3]. Penanganan longsor umumnya dilakukan teknis dengan membangun tanggul penahan. Penggunaan tanggul lebih sesuai pada lahan dengan kemiringan tinggi (terjal). Pada lahan dengan kemiringan yang lebih rendah memungkinkan terjadinya proses revegetasi. Penelitian tentang jenis-jenis tanah longsor tanaman tahan umumnya berfokus pada tanaman berkayu seperti: lengkeng, durian, pinus dan kopi. Vegetasi pohon dapat membantu mencegah tanah dan meningkatkan stabilitas lereng bukit dengan memperkuat akarnya [4]. Spesies tanaman ini cocok untuk yang terakhir suksesi, sedangkan, dalam situasi sebelumnya, tanaman terbaik adalah kelompok perintis.

Teknik revegetasi dalam dilakukan secara manual dengan menanam biji atau semai secara langsung, maupun dengan cara mengembangkan teknik lain seperti aplikasi teknologi hydroseeding. Teknik ini telah banyak diterapkan pada lereng besar dan curam di daerah beriklim sedang namun belum banyak diterapkan untuk mengatasi lahan bekas tanah longsor yang cenderung menjadi lahan kritis di Indonesia.

Hydroseeding merupakan teknik penanaman benih dengan menggunakan campuran beberapa bahan terdiri atas bibit tanaman, penstabil tanah, air dan mulsa [5]. Formula ini lalu dimasukkan dalam tangki, kemudian disemprotkan di atas area lereng yang telah disiapkan di lokasi yang seragam. Metode hydrooseeding merupakan teknologi alternatif yang lebih mudah dibandingkan dengan metode manual untuk lahan luas atau lahan dengan aksesibilitas rendah misalnya lereng yang curam [6]. Hydroseeding dengan benih komersial rumput cepat tumbuh dan kacang-kacangan adalah praktik umum dalam revegetasi.

Hydroseeding dengan benih komersial cepat tumbuh rerumputan dan legum adalah praktik umum dalam revegetasi. Namun, penelitian tentang hydroseeding di Indonesia masih sedikit. Beberapa penelitian sebelumnya selalu dikaitkan dengan lahan pasca tambang [7][8]. Sementara itu, hydroseeding merupakan tindakan revegetasi yang memungkinkan untuk mengatasi kesulitan penanaman manual. Formula hydroseeding dapat diterapkan secara relatif luas dan daerah curam [6]. Pemilihan spesies tanaman yang tepat sangat penting untuk memastikan keberhasilan dan keberlanjutan revegetasi [9]. Stabilitas dari kemiringan sebagai target harus selaras dengan sekitarnya lingkungan. Tujuan ini mungkin berhasil dengan revegetasi, karena sistem akar tanaman dapat memperbaiki tanah agar tidak mengalami kelongsoran [4]. Tanaman penutup tanah dalam penelitian ini berfungsi sebagai menghambat erosi tanah akibat air hujan. Misalnya, pemilihan jenis rumput didasarkan pada kenyataan bahwa jenis ini dapat menutupi tanah dengan cepat dan melalui akar. Rumput adalah jenis yang biasa ditanam di awal tahapan revegetasi lahan karena merupakan spesies pionir [10]. Pemanfaatan benih 
untuk revegetasi tanah setelah longsor didasarkan pada pertimbangan bahwa tumbuhan ini memiliki sifat pionir dan berada pada tingkat yang tinggi kelimpahan. Secara ekologis, tumbuhan ini memiliki peran penting karena kemampuannya untuk tumbuh dan menjajah wilayah yang luas. Tujuan penelitian ini untuk menganalisis efek kemiringan terhadap tingkat pertumbuhan rumput jepang yang diterapkan dengan formula hydroseeding.

\section{Material dan Metode}

Penelitian ini dilakukan pada bulan Mei-September 2020 di rumah kaca dan Laboratorium Sentral, Malang Institut Pertanian. Campuran hydroseeding terdiri dari: bibit tanaman, kompos, pembenah tanah, pupuk kandang, dan air. Biji yang digunakan terdiri dari 0,5 gram (121 biji) $Z$. japonica. Biji Z. japonica direndam selama 24 jam dan diseleksi sebelum dimasukkan dalam campuran. Selain itu, untuk semua komposisi hydroseeding, Guar Gum dan campuran mikroorganisme lokal dicampur sampai diperoleh 7 liter mulsa koloid sehingga dapat dengan mudah diterapkan di atas permukaan media. Media terdiri dari tanah yang berasal dari longsor di Ngantang, Kabupaten Malang, Jawa Timur. Tanah itu ditempatkan dalam kotak plastik berukuran $38 \mathrm{~cm} \times 28 \mathrm{~cm} \times 13 \mathrm{~cm}$. Kotak plastik tesebut ditempatkan pada rangka besi yang memiliki tiga tingkat kemiringan, 30, 50, dan 70 derajat. Pemilihan tingkat kemiringan ini mengadopsi standar yang ada. Media kontrol terdiri dari tanah dan biji tanpa formula. Perlakuan tersebut memiliki tiga ulangan. Pengamatan perkecambahan dilakukan setiap minggu sampai minggu keenam. Perlakuan dilakukan di rumah kaca. Kecepatan perkecambahan biji ditentukan oleh persentase viabilitas benih/total benih yang diaplikasikan. Bibit tinggi badan diukur menggunakan jangka sorong. Data tinggi benih, dan jumlah tunas ditabulasi dan dikompilasi menggunakan Microsoft Excel. Perbedaan antar rata-rata perlakuan dianalisis menggunakan Analisis Variansi (ANAVA) uji Tukey HSD pada $=5 \%$ dengan SPSS 18.0 untuk Windows.

\section{Hasil dan Diskusi}

\section{Hasil Penelitian}

Pada media perlakuan, persentase pertumbuhan cenderung berfluktuasi dari minggu ke-0 hingga minggu keenam, kecuali pada kemiringan $70^{\circ}$. Persentase pertumbuhan tertinggi terjadi pada perlakukan hydroseeding dengan kemiringan $70^{\circ}$. Viabilitas tertinggi tersebut terjadi pada minggu kelima dan keenam (masing-masing 28.65\%). Pada media kontrol, persentase perumbuhan cenderung rendah, kecuali pada kontrol dengan kemiringan $30^{\circ}$. Viabilitas pada perlakuan dengan kemiringan $30^{\circ}$ dan $50^{\circ}$ mencapai persentase yang hampir sama yaitu 11 sd 13 . Pada kontrol $30^{\circ}$ ini persentase pertumbuhan tertinggi terjadi pada mingu kelima (13.5\%). Viabilitas pada kontrol dengan kemiringan $50^{\circ}$ dan $70^{\circ}$ mencapai persentase sangat rendah (kurang dari 2\%) (Gambar 1). 


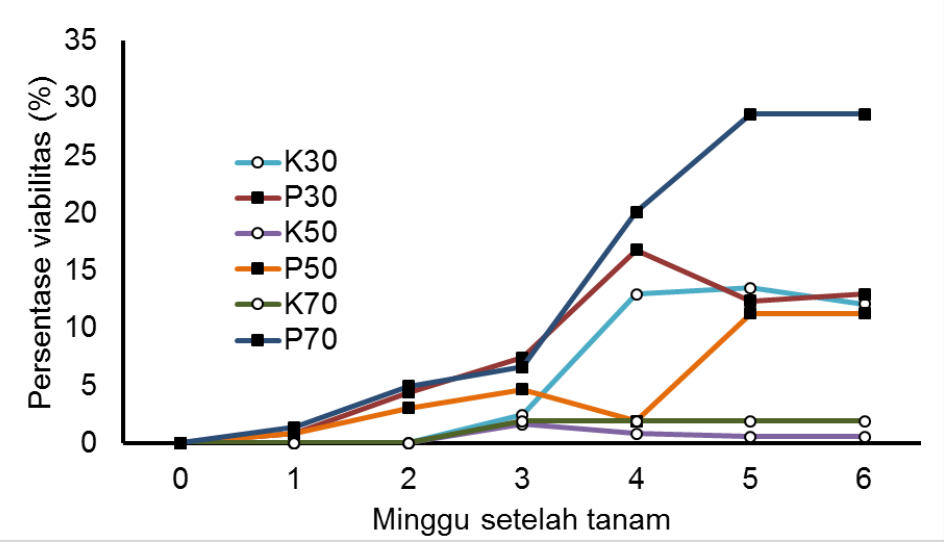

Gambar 1. Persentase Viabilitas

Pada semua perlakuan dengan formula hydroseeding, pertumbuhan sudah mulai berlangsung sejak minggu pertama, dan terus mengalami kenaikan panjang tanaman hingga minggu keenam. Pada perlakuan dengan formula hydroseeding $\left(30^{\circ}\right.$ dan $\left.70^{\circ}\right)$, pada minggu ke enam tinggi rumput mencapai ukuran lebih dari $5,6 \mathrm{~cm}$, sedangkan pada perlakuan $50^{\circ}$ tinggi rumput mencapai $4.7 \mathrm{~cm}$. Tinggi rumput pada perlakuan dengan formula hydroseeding lebih tinggi daripada pada kontrol. Pada semua media kontrol pertumbuhan baru dimulai mulai minggu kedua. Pada minggu keenam, pertumbuha rumput tertinggi mencapai $3.67 \mathrm{~cm}$ (pada kontrol 30 ), sedangkan terendah (pada kontrol $70^{\circ}$ ) hanya mencapai $1,9 \mathrm{~cm}($ Gambar 2).

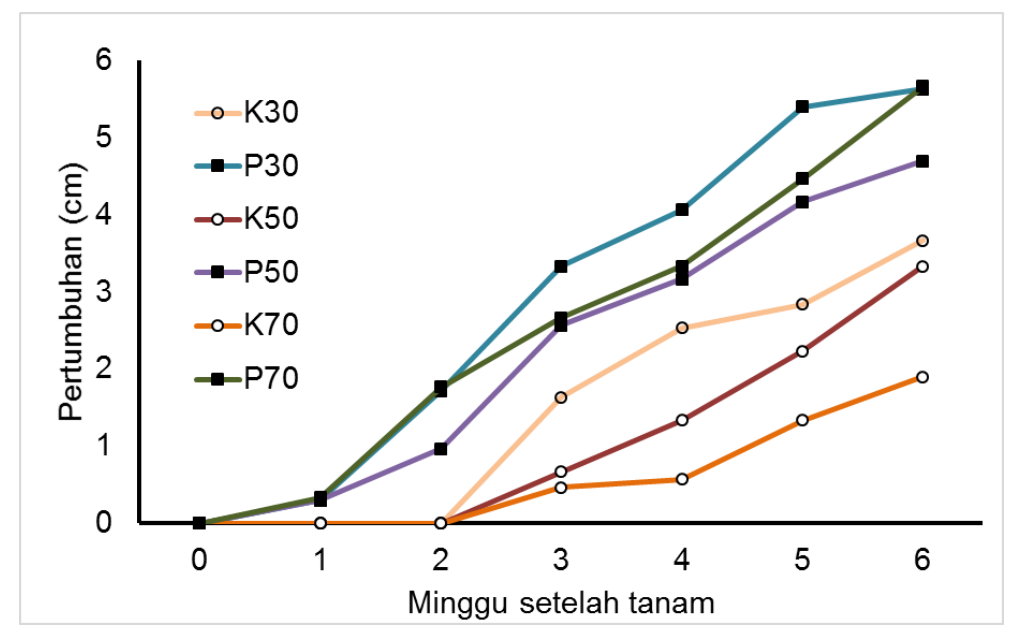

Gambar 2. Grafik Pertumbuhan

Hasil analisis statistik menunjukkan bahwa pengaruh perlakuan terhadap viabilitas benih $(\mathrm{F}=19.989)$ dan pertumbuhan $(\mathrm{F}=29.898)$ rumput jepang sangat signifikan $(\mathrm{p}<0.001)$, sedangkan pengaruh kemiringan hanya signifikan terhadap viabilitas benih $(\mathrm{F}=5.059 ; \mathrm{p}<0.01)$. Demikian juga pengaruh interkasi kedua faktor tersebut hanya signifikan terhadao viabilitas benih $(F=5.059 ; \mathrm{p}<0.01)$ (Tabel $1)$. 
e-Jurnal Ilmiah BIOSAINTROPIS (BIOSCIENCE-TROPIC)

Volume 7/ No.: 2 / Halaman 77 - 83 / Januari Tahun 2022

ISSN : 2460-9455 (e) - 2338-2805(p)

Tabel 1. Nilai F dan tingkat signifikansi pengaruh variabel bebas terhadap variabel terikat

\begin{tabular}{|l|l|l|}
\hline Variabel bebas & Variabel terikat & $\begin{array}{l}\text { Nilai F dan } \\
\text { signifikansi }\end{array}$ \\
\hline Perlakuan (p) & Viabilitas benih & $19.989^{* * *}$ \\
\hline & Pertumbuhan & $29.898^{* * *}$ \\
\hline Kemiringan (k) & Viabilitas benih & $5.059^{* *}$ \\
\hline Interaksi (p*k) & Viabilitas benih & $5.384 * *$ \\
\hline & Pertumbuhan & $0.967 \mathrm{~ns}$ \\
\hline
\end{tabular}

Signifikansi: $* * * \mathrm{p}<0.001 ; * * \mathrm{p}<0.01 ; \mathrm{ns} \mathrm{p}>0.05$

Hasil post-hoc test menunjukkan bahwa viabilitas benih pada kemiringan $30^{\circ}$ tidak berbeda bnyata dengan dengan kemiringan $70^{\circ}$; sedangkan kedua kemiringan ini lebih tinggi secara signifikan dibandingkan pada kemiringan $50^{\circ}$. Adapun pertumbuhan pada ketiga ketinggian tidak menunjukkan perbedaan yang signifikan

\section{Pembahasan}

Penelitian ini menunjukkan bahwa aplikasi hydroseeding dengan benih rumput Jepang ( $Z$. japonica) pada kemiringan $70^{\circ}$ dapat digunakan. Perlakuan hydroseeding pada kemiringan ini menghasilkan viabilitas benih dan laju pertumbuhan yang paling tinggi. Viabilitas pada kemiringan $30^{\circ}$ dan $50^{\circ}$ mencapai persentase yang hampir sama yaitu pada kisaran 11 sampai $13 \%$. Perlakuan hedroseeding pada kemiringan $70^{\circ}$ juga menghasilkan pertumbuhan rumput tertinggi. Yang menarik adalah pertumbuhan rumput pada kemiringan $70^{\circ}$ tidak berbeda nyata dibandingkan pertumbuhan pada kemiringan $30^{\circ}$. Pertumbuhan pada perlakuan dengan kemiringan $50^{\circ}$ cenderung lebih rendah, dibandingkan pada kemiringan $30^{\circ}$ dan $70^{\circ}$. Pada penelitian terdahulu juga diketahui bahwa beberapa tanaman pionir seperti kacangan (Pueraria javanica) dan rumput teki (Cyperus brevifolius) mampu tumbuh pada kemiringan hingga $70^{\circ}$, namun demikian berbeda dengan penelitian ini, pada penelitian tersebut pertumbuhan tertinggi terjadi pada kemiringan $50^{\circ}$ [11]. Artinya rumput jepang juga berpotensi untuk dijadikan tanaman pionir revegetasi lahan pasca longsor dengan kemiringan yang lebih curam dari kedua jenis tersebut.

Hasil penitian ini juga menunjukkan pengaruh formula hydroseeding terhadap pertumbuhan rumput cukup besar. Proses rehabilitasi lahan dengan menggunakan tanaman penutup tanah ini diharapkan mampu menutupi permukaan lereng yang curam pasca longsor dengan cara yang secepat mungkin untuk mengurangi erosi oleh limpasan hujan. Pengaruh formula hydroseeding yang signifikan terhadap pertumbuhan disebabkan karena keberadaan bahan organik dalam formula.

Persentase pertumbuhan yang besar dan tinggi semai pada media perlakuan menunjukkan pengaruh yang besar dari formula hydroseeding. Hal ini terjadi karena dalam formula hydroseeding dibuat dari beberapa bahan tersmasuk pupuk kandang untuk ketersediaan unsur hara tanah. Selanjutnya penambahan mikroorganisme lokal dalam campuran pupuk cair yang dipakai pada formula sangat mendukung proses dekomposisi yang dapat mempercepat tersedianya unsur hara yang dibutuhkan untuk pertumbuhan tanaman [12][13]. Sesuai dengan penelitian lain, kandungan pupuk organik pada media tanam berpengaruh nyata terhadap perkecambahan biji dan karakteristik pertumbuhan semai [14][15]. Hal ini juga didukung oleh penelitian yang lain. Pada penelitian terdahulu yang dilakukan oleh 
[16], menunjukkan bahwa perbedaan pemupukan dan media berpengaruh nyata terhadap pertumbuhan rumput jepang ( $Z$. japonica). Misalnya, penambahan pupuk anorganik pada media tanah Alfisol meningkatkan pertumbuhan (kualitas visual dan fungsional) terbaik pada spesies rumput ini. Pada penelitian lain juga dilaporkan bahwa tutupan tanah bervegetasi rumput jepang dapat meredam erosi sebesar $162 \mathrm{~kg} / \mathrm{m} / \mathrm{jam}$ [17].

Penggunaan mulsa dan kompos juga sangat mempengaruhi pertumbuhan tanaman pionir. Formula Hydroseeding untuk jenis benih Kyllingia monocephala, Cyperus brevifolius, C. eragrostis, C. odoratus, $C$. strigosus dan dengan campuran mulsa kompos kotoran kerbau yang ditanam pada media tanah pascatambang memiliki kerapatan semu tertinggi pada umur 20 hari setelah perlakuan yaitu 23 individu per pot dibandingkan dengan media lain [8]. Bahan lain dari formula hydroseeding juga memiliki pengaruh penting, seperti tackifier organik, yang membantu merekatkan benih pada media tanah untuk perlindungan biji dari erosi. Penelitian lain menyatakan bahwa campuran benih, tackifier organik, bioaktivator, superabsorben, bio-humus, mulsa serat selulosa, serat alami dan air sangat mendukung parameter perkecambahan benih dan produksi biomassa rumput. Formula hydroseeding ini secara signifikan mengurangi jumlah air limpasan melalui produksi lapisan penyerap [5]. Penggunaan teknik hydroseeding dengan jenis bahan penstabil tanah dari bahan lateks dan pembenah tanah pada campurannya tidak berpengaruh negatif terhadap pertumbuhan. Oleh karena itu, kedua jenis bahan penstabil tanah tersebut dapat digunakan dalam campuran hydroseeding [18].

Kemampuan vegetasi untuk memperkuat daya ikat tanah merupakan faktor penting dalam pemilihan jenis tumbuhan untuk restorasi ekosistem. Variabel vegetasi penting lainnya terkait dengan pertumbuhan tanaman seperti komposisi jenis vegetasi, tutupan vegetasi, dan kualitas bahan tambahan pada tanah juga dihasilkan oleh tanaman seperti kekuatan tarik, koefisien permeabilitas, tekstur tanah dan bahan organik. Aplikasi hydroseeding telah terbukti mengurangi limpasan dan hasil sedimen yang diamati di plot perlakuan. Hasil ini dapat dikaitkan dengan efek gabungan dari: (a) penerapan jerami dan mulsa ke permukaan tanah yang memberikan perlindungan terhadap dampak tetesan hujan dan (b) perbaikan umum struktur tanah yang disebabkan oleh amandemen organik [19].

\section{Kesimpulan}

Hasil penelitian ini menyimpulkan bahwa aplikasi hydroseeding dengan benih rumput Jepang $(Z$. japonica) pada media yang diletakkan dengan kemiringan $70^{\circ}$ potensial digunakan sebagai formula untuk proses revegetasi lahan bekas longsor. Perlakuan hydroseeding pada kemiringan ini menghasilkan viabilitas benih $(28.65 \%)$ dan laju pertumbuhan $(0.93 \mathrm{~cm} / \mathrm{minggu})$ yang paling tinggi.

\section{Daftar Pustaka}

[1] Didu. M.S, “Analisis posisi dan peran lembaga serta kebijakan dalam proses pembentukan lahan kritis," J. Teknol. Lingkung., vol. 2, no. 1, pp. 93-105, 2011.

[2] D. S. Hadmoko, F. Lavigne, J. Sartohadi, P. Hadi, and Winaryo, "Landslide hazard and risk assessment and their application in risk management and landuse planning in eastern flank of Menoreh Mountains, Yogyakarta Province, Indonesia," Nat. Hazards, vol. 54, no. 3, 2010, doi: 10.1007/s11069-009-9490-0.

[3] S. Stanchi, M. Freppaz, A. Agnelli, T. Reinsch, and E. Zanini, "Properties, best management practices and conservation of terraced soils in Southern Europe (from Mediterranean areas to the Alps): A review," Quat. Int., vol. 265, 2012, doi: 10.1016/j.quaint.2011.09.015.

[4] A. Stokes, C. Atger, A. G. Bengough, T. Fourcaud, and R. C. Sidle, "Desirable Plant root traits for protecting natural and engineered slopes against landslides," Plant and Soil, vol. 324, no. 1. 2009, doi: 10.1007/s11104-009-0159-y.

[5] A. Parsakhoo, M. Jajouzadeh, and A. Rezaee Motlagh, "Effect of hydroseeding on grass yield and water use efficiency on forest road artificial soil slopes," J. For. Sci., vol. 64, no. 4, 2018, doi: 10.17221/2/2018-JFS. 
e-Jurnal Ilmiah BIOSAINTROPIS (BIOSCIENCE-TROPIC)

Volume 7/ No.: 2 / Halaman 77 - 83 / Januari Tahun 2022

ISSN : 2460-9455 (e) - 2338-2805(p)

[6] J. Albaladejo Montoro, J. Alvarez Rogel, J. Querejeta, E. Díaz, and V. Castillo, "Three hydroseeding revegetation techniques for soil erosion control on anthropic steep slopes," L. Degrad. Dev., vol. 11, no. 4, 2000, doi: 10.1002/1099-145X(200007/08)11:4<315::AIDLDR394>3.0.CO;2-4.

[7] C. Thomas, A. Sexstone, and J. Skousen, "Soil biochemical properties in brown and gray mine soils with and without hydroseeding," SOIL, vol. 1, no. 2, 2015, doi: 10.5194/soil-1-621-2015.

[8] D. Yulianingsih, "Aplikasi Beberapa Mulsa Hydroseeding untuk Perkecambahan Biji Teki Pioner di Tanah Pasca Pertambangan Batubara dari Kalimantan Selatan," Biotropika, vol. 3, 2015.

[9] G. Oliveira, A. Clemente, A. Nunes, and O. Correia, "Limitations to recruitment of native species in hydroseeding mixtures," Ecol. Eng., vol. 57, 2013, doi: 10.1016/j.ecoleng.2013.04.015.

[10] Y. C. Chen, C. F. Wu, and S. H. Lin, "Mechanisms of forest restoration in landslide treatment areas," Sustain., vol. 6, no. 10, 2014, doi: 10.3390/su6106766.

[11] A. Zairina and Y. Q. Mondiana, "The effect of slope level and hydroseeding formula on the growth of cyperus brevifolius and pueraria javanica seedlings," Biodiversitas, vol. 21, no. 11, 2020, doi: 10.13057/biodiv/d211104.

[12] A. Zairina, A. . Leksono, and Y. . Mondiana, "The effect of earthworm casting media with organic liquid fertilizer on sandalwood (Santalum album L.)," Ecol. Environ. Conserv. Journals, vol. 25, no. November, pp. 39-43, 2019.

[13] A. S. Leksono, I. Mustafa, A. Afandhi, A. Zairina, and Y. Setyadin, "The effectiveness of banana tuber and goat rumen as bio activator of liquid biopesticide fertilizers," in IOP Conference Series: Earth and Environmental Science, 2019, vol. 391, no. 1, doi: 10.1088/1755-1315/391/1/012020.

[14] Anshari, B. E, F. A.A.R, and A. E., "Hydroseeding application using pioneer local plant seeds for coal postmining soil in Tanah Laut Regency, South Kalimantan," J. Degrad. Min. L. Manag., vol. 5, no. 53, pp. 2502-2458, 2018, doi: 10.15243/jdmlm.

[15] M. . Samir, Rai, Ratna, and B. Prasad, "Effect of organic manures on seed germination and seedling growth of khirni," vol. 142, no. December, pp. 666-669, 2016.

[16] Zu'amah H, "Domestifikasi Zoysia Japonica Dan Paspalum Vaginatum Sebagai Rumput Ornamental Pada Media Tanah Dan Pasir Dengan Penambahan Pupuk Organik Dan Anorganik," Universitas Negeri Solo, Solo, 2012.

[17] M. Pajri and Nurfadillah, "Analisis Pengaruh Vegetasi Terhadap Pencegahan Erosi Pada Lereng Tanah (Uji Eksperimental)," Universitas Muhammadiyah, Makasar, 2021.

[18] S. Y. Mulyani, "Studi Komparasi Pemanfaatan Bahan Pemantap Tanah Jenis Lateks dan Polyacrilamide (Pam) dalam Campuran Hydroseeding terhadap Pertumbuhan Vegetasi Jenis Rumput dan Cover Crop,” J. Soshum Insentif, 2018, doi: 10.36787/jsi.v1i1.30. 